consists of two suit-case units, one of which contains the power unit operating either from the electricity supply mains or from a car-starter battery. The other unit comprises the transmitter, which conforms with the C.C.I.T. requirements as regards pieture size, rate of scanning, synchronizing, phasing and speed of transmission; it can therefore be used in conjunction with any make of receiver similarly standardized. As with the fixed station equipment, the speed of the revolving drum carrying the picture is maintained constant by means of a special synchronizing circuit controlled by a temperaturecompensated high-stability tuning fork. The frequency of this fork is $1,020 \mathrm{c} / \mathrm{s}$., and this is used to modulate a sub-carrier signal of $1,300 \mathrm{c} / \mathrm{s}$., which is transmitted down the line, to provide at the receiver a synchronizing signal which is independent of any changes occurring in the telephone carrier-signal.

There is also available a portable dark-room, comprising a small tent and full photographic facilities, and this is fitted up in two suit-cases for use with the portable picture transmitter. This equipment allows the processing of pictures to be carried out quickly and conveniently in any location.

The bulletins referred to above contain several photographic reproductions in support of the claim that "Muirhead machines are producing the best wired pictures in the world".

\section{ifl \\ ANCIENT ARTS AND MODERN PARODIES}

T HË exhibition entitled "40,000 Years of Modern Art", which opened at the Academy Hall in Oxford Street, London, just before Christmas and closes at 10 p.m. on January 29 , makes no claim to a scientifig appor ch-to which, indeed, so cavalier a title of ald a $\mathrm{f}$ been rather ill attuned-yet it posepses sr rpastung interest for anthropologists, and mat well do a good service to science by inducing them, and other visitors, to look at primitive art in new ways under the shock of the juxtaposition with a sufficiently aggressive selection of modern paintings and sculptures. The Institute of Contemporary Arts, 6 Fitzroy Street, London, W.1, a recently formed body devoted to the good cause of encouraging new trends in all the arts (but the approach of which is perhaps not yet quite so wide as its scope), is to be warmly congratulated and thanked for assembling what is almost certainly the most impressive display of primitive art ever held in Great Britain outside the great ethnographical museums.

The selection, though partly conditioned by the desire to find parallels for the moderns, has not suffered unduly thereby, and there are only a few pieces (such as a dubious Easter Island figure) which seem to have been included less for their merit than their surrealism. Many, if not most, of the Oceanic and (especially) African pieces are of the very first class within their types; some cannot be paralleled here at all. The Pitt Rivers and Ashmolean Museums at Oxford, the Horniman Museum and the Brighton Museum have all made notable contributions, and the magnificent private collections of Mr. Webster Plass and Mr. W. O. Oldman have been drawn upon to excellent effect. Among the finest pieces are the most forceful of all Basonge masks (Belgian Congo), owned by Mr. R. Penrose; Mr. Plass' bust of a Baga fertility divinity (French Guinea); the Northern Yoruba earth goddess from the Horniman Museum; two large fetish figures of the eastern and western Belgian Congo from the Oldman collection; some fine reproductions from the Frobenius Institute at Frankfurt of Australian and African rock paintings; and an outstanding series of polychrome malanggan carvings from the New Ireland collection at Brighton. The word 'primitive' has been rather strictly interpreted, to exclude the barbaric 'civilizations' of West Africa, Indonesia and pre-Columbian America, and this has meant that certain forms of sculpture preeminently appropriate to this exhibition (such as the more mystical of the Benin bronzes) are unrepresented. Less easy to explain is the truly primitive sculpture of Borneo and other parts of the East Indies.

The declared purpose of the exhibition is to compare primitive and modern and to suggest a community of inspiration between them. But one's main impression on leaving the show (and this is confirmed by most of the art critics) is rather of antithesis. It is true that there are superficial resemblances of form (though many of those to which the organisers direct attention are, in fact, purely fortuitous); but fundamentally they are opposed in conception and function. Primitive art is everywhere (even in medieval Europe) an art of conformity, of devoted acceptance in both a spiritual and a material sense; the forms develop over hundreds, or even thousands, of years, by processes which are essentially evolutionary, and have a four-dimensional quality about them which arises from their conception not by a single artist, but by many generations of artists, not as an escape, but as at once the expression and the support of the social pattern. 'Modern' art, on the contrary, is to a large extent frankly revolutionary, and, moreover, is still, after forty years, in the destructive phase of anarchism, comparatively few artists having begun, like Henry Moore (who almost alone in this exhibition seems to hold his own with the peoples of Nature), to build the foundations of a new order amid the chaos; too many of them are iconoclasts, content to satirize our world by drawing, for their purely intellectual inspiration, upon the form but not the content of the deeply religious art of the primitive peoples (with the same cynicism with which an atheistic totalitarianism will tolerate or even sponsor a subservient form of Christianity for its own ends). In this deeper sense, then, primitive art is actually nearer in spirit to the traditionalism of the Royal Academy than to the exuberance of its own imitators. Sincerity, it may be thought, is the most flattering form of imitation.

We may be all the more grateful to the Institute of Contemporary Arts for putting the moral so clearly before us that there is a virtual unanimity among both critics and members of the public. The Institute has thus laid a fine foundation for its future work, and we may look to it with confidence and hope for the constructive leadership which will not only give direction and stability to modern art in the postPicasso era, but also make its contribution to a re-integration of the cultural elements in our schizophrenic society.

Two further words should be said: the arrangement of the exhibition, though bold and imaginative, strains perhaps a little too self-consciously after the sales technique of a show of industrial design, instead of the self-effacement proper to the display of works 
of art; and the catalogue (though not wholly innocent of the same tendency) contains an essay by W. G. Archer and Robert Melville which is a valuable stimulant to thought about primitive and modern art and their interrelations, and in which both artists and ethnologists may find not a few provocative sentences. We may hope that the collaboration between art and science will be pushed much further.

$6 \mid \hat{t}$

WILLIAM FAGG

\section{SECULAR CHANGES IN THE EARTH'S MAGNETIC FIELD}

R. E. CABUNARD has described (Mon. Not. Roy. As. Soc., Geophys. Supp., 5, No. 7, July 19N. the rapid changes in the earth's magnetic field in South Africa, from which certain tentative OAdysions are drawn. From data in tables 25, 29 an 33 in "Descriptions of the Earth's Main Magnetic Field and its Secular Changes", by E. H. Vestine and others (Carnegie Institution, Washington, 1947), a diagram is constructed showing the annual changes in the horizontal and vertical fields in South Africa at 1922.5 ; this date has been chosen because it is believed that the secular variations are better known then than at any other time.

From detailed calculations it seems possible that motions in the liquid core of the earth can partly explain the rapidity of change, though, as shown in the calculations, it is difficult to obtain a sufficient field by these means. Some of this difficulty, it is hoped, may be removed by a more thorough analysis of the secular change. The movement of the material of the earth's core through the general magnetic field of the earth could induce electric currents which produce the secular changes in the magnetic field, and the world-wide part of the change may be due to motions some thousands of kilometres in diameter. From 1843 to 1900 the change at Cape Town was comparatively small $(0.02$ gauss in all $)$ and may not have been due to a local eddy.

No explanation is given regarding the causes of the motions in the liquid core, but it is suggested that radioactive generation of heat there might produce thermal convective currents. A similar effect would result from asymmetry in the earth's cooling, and another possibility is that the slipping of the outer part of the earth over the core, while the earth's rotation slows down by tidal friction, may have had some effect.

A full investigation of the theory proposed would be a tedious matter, and it is not suggested that it is complete at present, but it is hoped that it will "stimulate modifications that will agree more exactly with the very complicated facts".

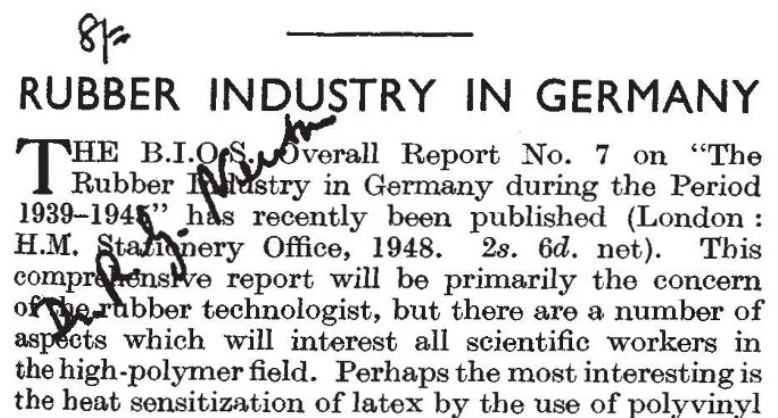

ether ('Igevin M50'), because the process depends upon the curious fact that this material is soluble in latex or water at room temperatures, but becomes insoluble at $35^{\circ} \mathrm{C}$., and causes the rubber to coagulate as it separates out. 'Igevin M50' is used in 3-7 per cent concentration referred to the rubber content, and the mixed solution is indefinitely stable at $25^{\circ} \mathrm{C}$., thus contrasting markedly with other heat-sensitizing materials.

The German synthetic rubber industry started long before the American industry, and it has been of interest to note that, in each case, the bulk of the synthetic rubber produced was of the butadienestyrene type, with butadiene-acrylonitrile polymers running second. What has not been generally realized, however, is that the Germans also had a large number of varieties, not only of the butadiene-styrene type, but also of other types, and these are described on pages 22-30 of the report. Two promising polymers of which little has previously been heard are 'Buna $\mathrm{K}$ ', a copolymer of butadiene and methyl vinyl ketone, and 'Buna M', where butadiene was polymerized with methyl methacrylate.

Another synthetic rubber which seems to show remarkable promise is 'Vulkollan N'. This is an ester-type rubber, prepared from polyethylene adipate and naphthalene di-isocyanate, which it is claimed will render all other polyester rubbers obsolete, being non-hardening, of high tear-resistance, and having lower hysteresis. Its resistance to abrasion is said to be ten times that of natural rubber, the tear-resistance is 53 per cent higher, and the solvent resistance is equal to that of 'Perbunan'; it will be interesting to see whether the manufacture of this rubber can be made a commercial proposition.

In the field of testing, the Germans were actively aware of the prime importance of laboratory tests for the 'processability' of their polymers, and they developed many tests which will be of interest to those technologists who had to struggle with the intractable rubbers which were the early product of the American industry. Other subjects of particular interest to technologists are the new non-black reinforcing fillers 'Tonerdegel' and 'White Carbon', the account of abrasion machines, and the discussion of thermal plasticization. R. G. NEwTON

\section{FORTHCOMING EVENTS}

\section{1=}

(Meetings marked with an asterisk * are open to the public)

Monday, January 24

UNIVERSITy LoNDON (in the Physiology Theatre, University College, fow street, London, W.C.1), at 4.45 p.m.-Dr. P. Johnson: "The Ut race trifuge and Electrophoresis Apparatus in Protein

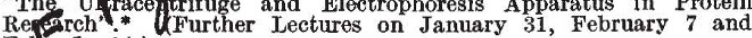
Feh outry 14.)

ROYal Geographical Soctery (at Kensington Gore, London, S.W.7), at 5 p.m.-Prof. C. G. Rossby: "Air Mass Meteorology-its Geographical Implications"

INSTITUTION OF ELECTRICAL ENGINEERS (at Savoy Place, Victoria Embankment, London, W.C.2), at 5.30 p.m.-Discussion on "Generation of Electricity by Gas Turbine Plant". MANCHESTER LITERARY AND PHILOSOPHICAL SOCIETY (in the
Reynolds Hall, College of Technology, Manchester), at $5.30 \mathrm{p.m} .-$ Reynolds Hall, College of Technology, M
Symposium on "Juvenile Delinquency".*

ThXTILE Institute, YorkshIRE SECTion (at Alexandra Café, King Edward Street, Halifax), at 7.30 p.m.-Mr. F. L. Goodall:" "The Battle against Textile Pests".

Chemical Societry, Oxford Section (in the Physical Chemistry Laboratory, Oxford), at $8.15 \mathrm{p} . \mathrm{m} \rightarrow$ Prof. N. V. Sidgwick F.R.S.

"Some Remarks on the Periodic Table" (Alembic Club Lecture).

\section{Tuesday, January 25}

INSTITUTE of FUEL (at the Institution of Mechanical Engineers Storey's Gate, St. James's Park, London, S.W.1), at 10 a.m. and 2 p.m.-Conference on "Combined Heat and Power Supplies"." 